\title{
Article \\ Wheat Grain Protein Content under Mediterranean Conditions Measured with Chlorophyll Meter
}

\author{
Marta Aranguren (D), Ander Castellón and Ana Aizpurua * \\ Department of Plant Production and Protection, NEIKER-Basque Institute for Agricultural Research and \\ Development, Basque Research and Technology Alliance (BRTA), Parque Científico y Tecnológico de Bizkaia, \\ P812, 48160 Derio, Biscay, Spain; maranguren@neiker.eus (M.A.); acastellon@neiker.eus (A.C.) \\ * Correspondence: aaizpurua@neiker.eus
}

Citation: Aranguren, M.; Castellón, A.; Aizpurua, A. Wheat Grain Protein Content under Mediterranean Conditions Measured with Chlorophyll Meter. Plants 2021, 10, 374. https://doi.org/10.3390/ plants10020374

Academic Editor: Martin Kulhanek Received: 28 January 2021

Accepted: 11 February 2021

Published: 15 February 2021

Publisher's Note: MDPI stays neutral with regard to jurisdictional claims in published maps and institutional affiliations.

Copyright: (c) 2021 by the authors. Licensee MDPI, Basel, Switzerland. This article is an open access article distributed under the terms and conditions of the Creative Commons Attribution (CC BY) license (https:// creativecommons.org/licenses/by/ $4.0 /)$.
Abstract: Adequate $\mathrm{N}$ fertilisation is crucial to increase the grain protein content (GPC) values in wheat. The recommended level of GPC needed to achieve high-quality bread-making flour should be higher than $12.5 \%$. However, it is difficult to ensure the GPC values that the crop will achieve because $\mathrm{N}$ in grain is derived from two different sources: $\mathrm{N}$ remobilized into the grain from $\mathrm{N}$ accumulated in the pre-anthesis period, and $\mathrm{N}$ absorbed from the soil in the post-anthesis period. This study aimed to (i) evaluate the effect of the application of $\mathrm{N}$ on the rate of stem elongation (GS30) when farmyard manures are applied as initial fertilisers on GPC and on the chlorophyll meter (CM) values at mid-anthesis (GS65), (ii) establish a relationship between the CM values at GS65 and GPC, and (iii) determine a minimum CM value at GS65 to obtain GPC values above $12.5 \%$. Three field trials were performed in three consecutive growing seasons, and different $\mathrm{N}$ fertilisation doses were applied. Readings using the CM Yara N-Tester ${ }^{\mathrm{TM}}$ were taken at GS65. The type of initial fertiliser did not affect the GPC and CM values. Generally, the greater the N application at GS30 is, the higher the GPC and CM values are. CM values can help to estimate GPC values only when yields are below $8000 \mathrm{~kg} \mathrm{ha}^{-1}$. Additionally, CM values at GS65 should be higher than 700 to achieve high-quality bread-making flour (12.5\%) at such yield levels. These results will allow farmers and cooperatives to make better decisions regarding late-nitrogen fertilisation and wheat sales.

Keywords: Triticum aestivum; Precision Agriculture; Yara N-Tester ${ }^{\mathrm{TM}}$; bread-making flour

\section{Introduction}

In order to feed a growing population, it is imperative to have increasing wheat grain yields and high grain quality. Grain quality is characterized in different ways, such as hardness, specific weight, Chopin Alveograph, Zeleny volume, and Hagberg number [1], but the main indicator is the grain protein content (GPC, [2]). Grain protein content prediction is complex because it depends on several aspects related to crop nitrogen (N) utilization, such as genetics (variety), environmental factors, and agronomic management practices such as $\mathrm{N}$ fertiliser application [3]. $\mathrm{N}$ fertilisation is a crucial factor for increasing yields and GPC. The amount of $\mathrm{N}$ applied to wheat must be carefully managed to the balance yield, grain quality, and environment needs, adjusting the $\mathrm{N}$ supply and crop requirements [4]. However, it is difficult to increase grain yield and quality concurrently due to its negative relationship [5].

In the area where this study was located (Araba, Basque Country, northern Spain), low GPC values have been reported due to the high yields achieved [2]. Additionally, the varieties commonly used have been selected to obtain high yields rather than obtaining high GPC. In this area, the beginning of the tillering (GS21, [6]) and stem elongation (GS30, [6]) growing stages are clues to establishing the required $\mathrm{N}$ fertilisation. The usual application rate is $40-60 \mathrm{~kg} \mathrm{~N} \cdot \mathrm{ha}^{-1}$ at GS21, and a greater but variable application at GS30. In some cases, a third late $\mathrm{N}$ fertiliser application at leaf-flag emergence (GS37, [6]) has 
also been considered to increase the grain $\mathrm{N}$ concentration because weather conditions are humid around the fertilisation moment (beginning of May in our conditions; [2]).

The $\mathrm{N}$ utilization of crops involves several processes, such as $\mathrm{N}$ uptake, assimilation, translocation, and remobilization [7]. Grain $\mathrm{N}$ is derived from two different $\mathrm{N}$ sources: $\mathrm{N}$ that is absorbed in the post-anthesis period from the soil (GS60-GS90; [6]) and N remobilized to the grain that was accumulated in vegetative organs in the pre-anthesis period (until GS60). After anthesis, vegetative organs behave as $\mathrm{N}$ sources, protein hydrolysis occurs, and amino acids are transported to the grain [7]. Thus, a large proportion of $\mathrm{N}$ in grain (60-95\%) might come from $\mathrm{N}$ remobilized rather than being taken from the soil [1], but it might depend on the weather conditions [2]. Thus, because the grain-filling process depends on several factors, the in-season assessment of GPC remains challenging in cereals. The recommended level of GPC for high-quality bread-making flour should be higher than $12.5 \%$ [8]. Farmers who grow cereals to achieve high-quality grain cannot predict if the crop will have the required protein standard [1]. The main concern is to ensure the GPC values that the crop will achieve and determine in advance whether an extra $\mathrm{N}$ rate is required. Not applying it when there is no need would benefit the farmer economically and would be environmentally friendly, avoiding $\mathrm{N}$ leaching and $\mathrm{N}$ gaseous losses [9]. Additionally, a better estimation of the GPC would help cooperatives improve the planning of their sales strategies because they could determine beforehand the percentage of grain that could be sold for bread-making flour or as animal feed.

Because a significant proportion of $\mathrm{N}$ in the grain has been remobilized from the leaves, stem, and roots of the plant in the post-anthesis period, it is reasonable to measure the $\mathrm{N}$ content from the shoot part at mid-anthesis (GS65, [6]) to predict GPC and anticipate whether a late $\mathrm{N}$ supply is necessary. Leaves are the most important organs in terms of $\mathrm{N}$ reserves, accounting for up to $50-62 \%$ of the total $\mathrm{N}$ of the plant [7]. The leaf flag was shown as a good indicator of the whole shoot N status at GS65 [1], and has been used to predict GPC in winter wheat [10]. Measuring $\mathrm{N}$ in the plant leaves is not practical because it requires destructive and time-consuming procedures such as sampling and laboratory analysis, making it impractical for farmers. In this sense, it is necessary to have rapid results and easy measurements of the shoot $\mathrm{N}$ status to develop reference values to decide whether a late $\mathrm{N}$ supply is necessary and predict the GPC at harvest.

Chlorophyll meters such as Minolta SPAD (Minolta corporation, Ltd., Osaka, Japan) or Yara N-Tester ${ }^{\mathrm{TM}}$ (Yara International ASA, Oslo, Norway) can provide instantaneous results for diagnostic purposes. Arregui et al. [11] and Ortuzar-Iragorri et al. [12] found good relationships between chlorophyll meters and $\mathrm{N}$ content of plant leaves in the same climatic conditions of the present field experiment, making them interesting to obtain rapid results. Relationships between remote sensing tool measurements against GPC have been studied in cereals, but there were no consistent results across locations and years $[10,13,14]$. In a previous study, Aranguren et al. [15] showed no general relationship across years between RapidScan CS-45 (NDVI (Normalized Difference Vegetation Index) and NDRE (Normalized Difference Red Edge)) or Yara N-Tester ${ }^{\mathrm{TM}}$ and GPC values under humid Mediterranean conditions. However, they detected that the relationship between the absolute chlorophyll meter values at GS65 (mid-anthesis; [6]) and GPC across years $\left(R^{2}=0.35\right)$ was improved compared with NDVI and NDRE [15]. They attributed that low predictability to the mentioned lack of consistency across years, as other authors have shown [1]. As previously mentioned, several variables, such as yield, the moment of crop $\mathrm{N}$ absorption, or remobilisation efficiency, might affect the grain filling process [13]. Therefore, based on previous results [15] and literature review [1,9,16], it was hypothesized that chlorophyll meter readings might be helpful in understanding GPC in wheat, but is necessary to study and understand the effect of other variables affecting the grainfilling process.

This study performed under humid Mediterranean conditions was aimed to (i) evaluate the effect of the application of a variable $\mathrm{N}$ rate at stem elongation (GS30) when farmyard manure is applied as initial fertilisers to chlorophyll meter values at mid-anthesis 
(GS65) and GPC values, (ii) determine the possibility of establishing a relationship between the chlorophyll meter values at GS65 and GPC, and (iii) establish the minimum chlorophyll meter value needed at GS65 to obtain GPC values above $12.5 \%$.

\section{Results}

The interaction among the growing season, initial fertilisation treatment, and $\mathrm{N}$ rate at GS30 was significant. Therefore, each factor was analysed depending on the other factors. The differences among the growing seasons are not presented in Tables 1 and 2 because of the high volume of data; thus, they are presented in supplementary Tables S1 and S2. However, if differences were mentioned in the main text, they were considered statistically significant.

\subsection{Wheat Grain Protein Content (GPC) and Yield}

The GPC varied from $7.4 \%$ to $10.9 \%$ in 2015 , from 7.5 to $10 \%$ in 2016 , and from 8.4 to $13.3 \%$ in 2017 (Table 1). In 2017, the GPC values were generally higher and the range of variation was wider than those in 2016 and 2015 (Table S1). In 2016, no differences were detected in the GPC values among the treatments (Table 1). However, in 2015 and 2017, significant differences were detected in the GPC values derived from the $\mathrm{N}$ rate applied at GS30, but not from the initial fertilisation treatments. In 2015, the highest GPC values were achieved with the $120 \mathrm{~kg} \mathrm{~N} \cdot \mathrm{ha}^{-1} \mathrm{~N}$ rate in conventional and dairy slurry treatments; however, in sheep manure, the highest GPC values were achieved with $160 \mathrm{~kg} \mathrm{~N} \cdot \mathrm{ha}^{-1}$. In 2017, the GPC values increased together with the $\mathrm{N}$ rates applied at GS30. GPC values above $12.5 \%$ were only achieved in 2017 with the highest $\mathrm{N}$ rate applied at GS30 (160 kg N.ha $\left.{ }^{-1}\right)$.

The amount of mineral $\mathrm{N}$ fertiliser at GS30 significantly influenced the yield values in the three growing seasons. The wheat grain yield varied between 4300 and $8700 \mathrm{~kg} \cdot \mathrm{ha}^{-1}$ in 2015, 6000 and $10800 \mathrm{~kg} \cdot \mathrm{ha}^{-1}$ in 2016, and 3400 and $7000 \mathrm{~kg} \cdot \mathrm{ha}^{-1}$ in 2017 (Table 1). The maximum wheat grain yields were achieved with $80 \mathrm{~kg} \mathrm{~N} \cdot \mathrm{ha}^{-1}$ applied at GS30 in 2015 under all the initial fertilisation treatments (conventional, dairy slurry, and sheep manure) and in 2016 and 2017 under conventional and dairy slurry initial fertilisation treatments. The maximum wheat grain yields were achieved with $120 \mathrm{~kg} \mathrm{~N} \cdot \mathrm{ha}^{-1}$ applied at GS30 in 2016 and 2017 with sheep manure treatments.

\subsection{Yara N-Tester ${ }^{T M}$ Readings and GPC Prediction}

At the GS65 growing stage, the lowest Yara N-Tester ${ }^{\mathrm{TM}}$ values were 470,450 , and 460 for 2015, 2016, and 2017, respectively, and the highest values were 660, 610, and 710 for the same years, respectively (Table 1). In 2015, with conventional treatment, the highest Yara N-Tester ${ }^{\mathrm{TM}}$ values were achieved with the $80 \mathrm{~kg} \mathrm{~N} \cdot \mathrm{ha}^{-1}$ rate applied at GS30, with dairy slurry treatment with the $160 \mathrm{~kg} \mathrm{~N} \mathrm{ha}^{-1}$ rate, and with sheep manure at the $120 \mathrm{~kg} \mathrm{~N} \cdot \mathrm{ha}^{-1}$ rate. In 2016, with conventional treatment, no differences were found in the Yara N-Tester ${ }^{\mathrm{TM}}$ readings. In 2016, with the dairy slurry treatment, the maximum Yara N-Tester ${ }^{\mathrm{TM}}$ values were achieved with the $80 \mathrm{~kg} \mathrm{~N} \cdot \mathrm{ha}^{-1}$ rate applied at GS30, and with sheep manure with the $120 \mathrm{~kg} \mathrm{~N} \mathrm{ha}^{-1}$ rate. In 2017, (Table 1), under the three initial fertilisation treatments, the Yara N-Tester ${ }^{\mathrm{TM}}$ maximum values were achieved with the $120-\mathrm{kg} \mathrm{N} \cdot \mathrm{ha}^{-1}$ rate. 


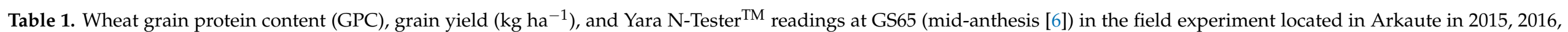
and 2017.



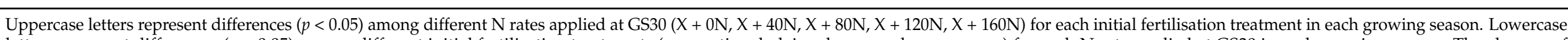


uppercase or lowercase letters indicates that no significant differences $(p>0.05)$ were detected. $n d$, no data; $\pm s d$ (standard deviation); $0 \mathrm{~N}$ and $280 \mathrm{~N}$ were not included in ANOVA. 
Table 2. Wheat crop total $\mathrm{N}$ content at harvest $\left(\mathrm{kg} \mathrm{N} \mathrm{ha}^{-1}\right)$ and increase in the $\mathrm{N}$ content in the aerial part of the crop ( $\mathrm{kg} \mathrm{N} \mathrm{ha}^{-1}$ ) during the post-anthesis period (from GS65 to harvest).

\begin{tabular}{|c|c|c|c|c|c|c|}
\hline \multirow[b]{2}{*}{ Treatment } & \multicolumn{2}{|c|}{2015} & \multicolumn{2}{|c|}{2016} & \multicolumn{2}{|c|}{2017} \\
\hline & Grain Total N & $\begin{array}{l}\text { Post-Anthesis } \\
\text { N Increase }\end{array}$ & Grain Total N & $\begin{array}{l}\text { Post-Anthesis } \\
\text { N Increase }\end{array}$ & Grain Total N & $\begin{array}{l}\text { Post-Anthesis } \\
\text { N Increase }\end{array}$ \\
\hline $40 N+0 N$ & $66 \pm 17 \mathrm{D}$ & $10 \pm 1$ & $84 \pm 18 \mathrm{D}$ & $31 \pm 11$ & $70 \pm 3 E$ & $30 \pm 6 a$ \\
\hline $40 \mathrm{~N}+40 \mathrm{~N}$ & $90 \pm 14 C$ & $32 \pm 9$ & $113 \pm 17 \mathrm{C}$ & $51 \pm 18$ & $88 \pm 11 \mathrm{D}$ & $18 \pm 5$ \\
\hline $40 \mathrm{~N}+80 \mathrm{~N}$ & $116 \pm 12 \mathrm{~B}$ & $21 \pm 6$ & $130 \pm 19 \mathrm{~B}$ & $31 \pm 2$ & $112 \pm 6 C$ & $37 \pm 11$ \\
\hline $40 \mathrm{~N}+120 \mathrm{~N}$ & $132 \pm 14 \mathrm{AB}$ & $10 \pm 5$ & $157 \pm 17 \mathrm{AB}$ & $59 \pm 22$ & $128 \pm 13 \mathrm{~B}$ & $11 \pm 6$ \\
\hline $40 \mathrm{~N}+160 \mathrm{~N}$ & $149 \pm 20 \mathrm{~A}$ & $20 \pm 4$ & $168 \pm 33 \mathrm{~A}$ & $44 \pm 18$ & $146 \pm 6 \mathrm{~A}$ & $28 \pm 9$ \\
\hline $\mathrm{DS}+0 \mathrm{~N}$ & $59 \pm 8 \mathrm{D}$ & $15 \pm 5$ & $96 \pm 24 \mathrm{C}$ & $53 \pm 26$ & $53 \pm 4 \mathrm{E}$ & $13 \pm 5 b$ \\
\hline $\mathrm{SM}+0 \mathrm{~N}$ & $58 \pm 5 \mathrm{D}$ & $6 \pm 2$ & $101 \pm 29 \mathrm{C}$ & $43 \pm 14$ & $51 \pm 3 \mathrm{E}$ & $19 \pm 3 b$ \\
\hline $0 \mathrm{~N}$ & $51 \pm 4$ & $17 \pm 7$ & $63 \pm 17$ & $24 \pm 8$ & $46 \pm 4$ & 11 \\
\hline
\end{tabular}

Uppercase letters represent differences among different $\mathrm{N}$ rates applied at GS30 $(40 \mathrm{~N}+0 \mathrm{~N}, 40 \mathrm{~N}+40 \mathrm{~N}, 40 \mathrm{~N}+80 \mathrm{~N}, 40 \mathrm{~N}+120 \mathrm{~N}, 40 \mathrm{~N}+160 \mathrm{~N})$ for each initial fertilisation treatment. Lowercase letters represent differences $(p<0.05)$ among different initial fertilisation treatments (conventional, dairy slurry, or sheep manure) for the $0 \mathrm{~kg} \mathrm{~N} \cdot \mathrm{ha}^{-1}$ rate applied at GS30 in each growing season. The absence of uppercase or lowercase letters indicates that no significant differences $(p>0.05)$ were detected. $\pm s d$ (standard deviation); $0 \mathrm{~N}$ was not included in ANOVA. DS, dairy slurry; SM, sheep manure.

In 2016, the Yara N-Tester ${ }^{\mathrm{TM}}$ values at GS65 could not explain the GPC variability (Figure 1b). However, in 2015 and 2017, the Yara N-Tester ${ }^{\mathrm{TM}}$ values at GS65 could explain $68 \%$ and $77 \%$ of the GPC variability, respectively (Figure 1a,c). The Cate-Nelson procedure can identify the critical level that best divides the data into two populations. The points in quadrant II represent the population with the highest GPC values, and those in quadrant IV the population with the lowest GPC values. The critical level is that at which $R^{2}$ reaches a maximum. The Yara N-Tester ${ }^{\mathrm{TM}}$ critical value dividing the two populations was 619 in 2015 and 591 in 2017. The GPC critical value obtained was 11.23 in 2015 and 10.29 in 2017. In 2015, the number of points in quadrant II was much lower than that in quadrant IV. In 2017, the dispersion of the points in the relationship was uniform in quadrants II and IV. The points located in quadrants I and III are considered outliers and correspond to the overestimation or underestimation of GPC, respectively. The error of the Yara N-Tester ${ }^{\mathrm{TM}}$, calculated as the percentage of outliers in relation to the total of points, was $28 \%$ in 2015 and $6 \%$ in 2017. In 2015, there were more error points mainly located in quadrant III (underestimation) and corresponding to yields higher than $8000 \mathrm{~kg} \mathrm{ha}^{-1}$. Thus, the Yara $\mathrm{N}-$ Tester $^{\mathrm{TM}}$ and GPC values differ in their relationship when the yields are lower or higher than $8000 \mathrm{~kg} \mathrm{ha}^{-1}$. When the yields are lower than $8000 \mathrm{~kg} \mathrm{ha}^{-1}$, the relationship between the Yara N-Tester ${ }^{\mathrm{TM}}$ values and GPC values increase linearly; when the yields are higher than $8000 \mathrm{~kg} \mathrm{ha}^{-1}$, the relationship is unclear.

Therefore, the coefficients of determination $\left(R^{2}\right)$ for the relationships between Yara $\mathrm{N}-$ Tester $^{\mathrm{TM}}$ values at GS65 and GPC were calculated based on the $8000 \mathrm{~kg} \mathrm{ha}^{-1}$ yield. When the yields were lower than $8000 \mathrm{~kg} \mathrm{ha}^{-1}$, the capacity to predict the GPC variability from Yara N-Tester ${ }^{\mathrm{TM}}$ readings was similar among the three growing seasons $\left(R^{2}=0.75\right.$; Figure 2a). Yields lower than $8000 \mathrm{~kg} \mathrm{ha}^{-1}$ in 2015 occurred in the three lowest $\mathrm{N}$ rates $(0$, 40 , and 80 at GS30) under DS and SM treatment and in the two lowest rates ( 0 and 40 at GS30) under conventional treatment. In 2016, yields lower than $8000 \mathrm{~kg} \mathrm{ha}^{-1}$ occurred with $\mathrm{X}+0 \mathrm{~N}$ treatment, and in 2017 with all treatments. The error of Yara $\mathrm{N}$-tester ${ }^{\mathrm{TM}}$ calculated as the percentage of outliers in relation to the total of points was $5 \%$. When the yields were higher than $8000 \mathrm{~kg} \mathrm{ha}^{-1}$, no significant relationship was found between GPC and Yara $\mathrm{N}$-tester ${ }^{\mathrm{TM}}$ readings at GS65 (Figure $2 \mathrm{~b}$ ). 

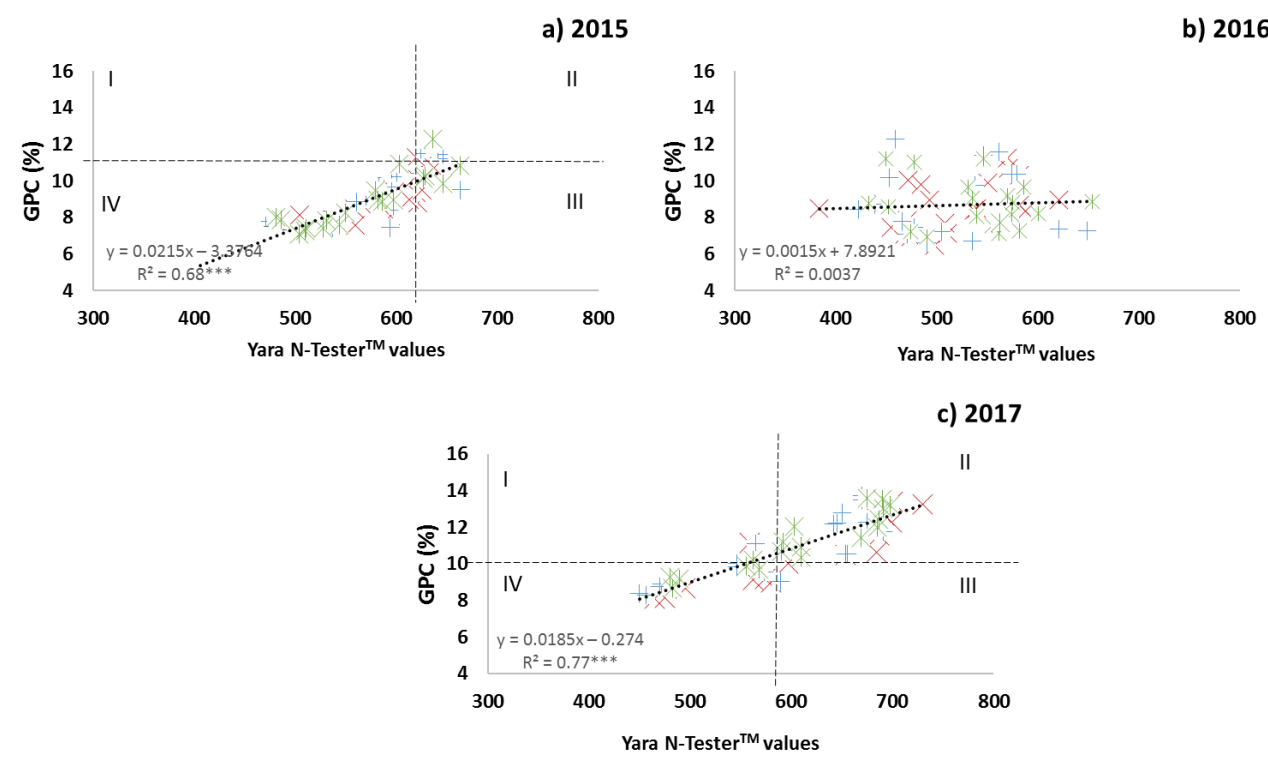

Figure 1. Relationship between the Yara N-TesterTM values at GS65 and\% GPC in the 2015 (a), 2016 (b), and 2017 (c) growing seasons at Arkaute. Type of initial fertilisation: Conventional +; DS: Dairy slurry x; SM: Sheep manure *. The linear model was fitted. ${ }^{* * *}$, significant at the 0.001 probability level. Strip lines indicate the critical $x$ value and critical $y$ value separating the data into four quadrants following the Cate-Nelson procedure. The Roman numerals indicate the quadrant of the plot. The data inside quadrants II and IV are concordant with the regression. The data inside quadrants I and III are not in concordance.
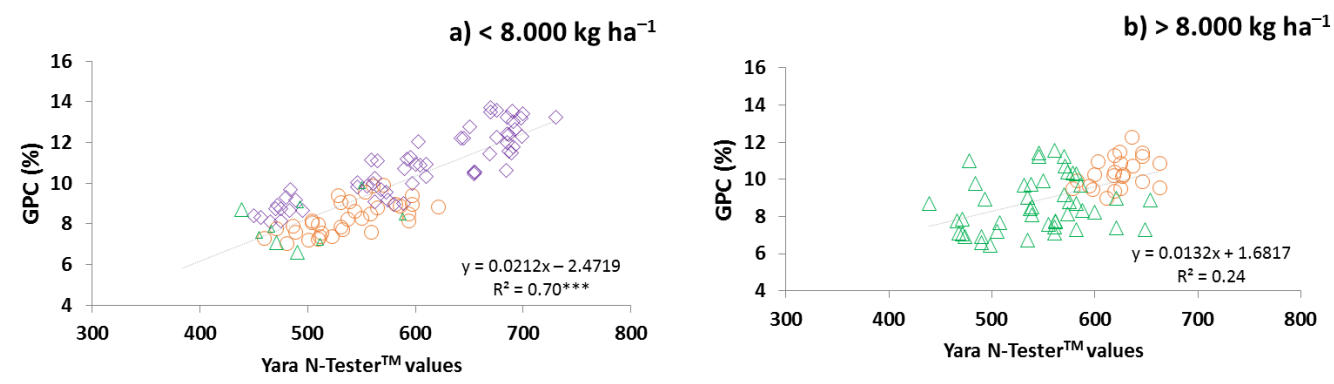

Figure 2. Relationship between the Yara N-Tester ${ }^{\mathrm{TM}}$ values at GS65 (mid-anthesis; Zadoks et al., 1974) and GPC (\%) when the wheat grain yields are lower than $8000 \mathrm{~kg} \mathrm{~N} \mathrm{ha}^{-1}$ (a) and when the wheat grain yields are higher than $8000 \mathrm{~kg} \mathrm{ha}^{-1}(\mathbf{b})$ in the field study at Arkaute. Wheat growing seasons: $2015 ; 2016 \Delta ; 2017 \diamond$. The linear model was fitted. ${ }^{* * *}$, significant at the 0.001 probability level. Strip lines indicate the critical $\times$ value and critical y value separating the data into four quadrants following the Cate-Nelson procedure. The Roman numerals indicate the quadrant of the plot. The data inside quadrants II and IV are concordant with the regression. The data inside quadrants I and III are not in concordance.

\subsection{Factors That Might Affect the GPC Predictability}

Regarding the grain total $\mathrm{N}$ at harvest (Table 2 and Table S2), in 2016, the values were generally higher (63-168 $\mathrm{kg} \mathrm{N} \mathrm{ha}^{-1}$ ) than those in 2015 (51-149 $\mathrm{kg} \mathrm{N} \mathrm{ha}^{-1}$ ) and 2017 (46-146 kg N ha ${ }^{-1}$ ). The higher the $\mathrm{N}$ rate is at GS30, the higher the grain total $\mathrm{N}$ values in the three growing seasons. In 2015 and 2016, the maximum values were achieved with the $120 \mathrm{~kg} \mathrm{~N} \mathrm{ha}^{-1}$ rate applied at GS30; however, in 2017, the maximum value was achieved with the highest $\mathrm{N}$ rate $\left(160 \mathrm{~kg} \mathrm{~N} \mathrm{ha}^{-1}\right)$. In 2016 , the $\mathrm{DS}+0 \mathrm{~N}$ and $\mathrm{SM}+0 \mathrm{~N}$ treatments presented higher values than the $40 \mathrm{~N}+0 \mathrm{~N}$ treatment.

No significant differences among the $\mathrm{N}$ treatments were detected in the post-anthesis $\mathrm{N}$ increase in the aerial part of the wheat crop from GS65 to harvest in any of the growing 
seasons (Table 2). However, treatments in the 2016 growing season presented a slightly higher $\mathrm{N}$ increase during the post-anthesis period $\left(24-59 \mathrm{~kg} \mathrm{~N} \mathrm{ha}^{-1}\right)$ than treatments in 2015 (6-32 kg N ha ${ }^{-1}$ ) and 2017 (11-37 kg N ha ${ }^{-1}$; Table S2). The differences between conventional treatment and treatments with organics as initial fertilisers without $\mathrm{N}$ application at GS30 ( $\left.0 \mathrm{~kg} \mathrm{~N} \mathrm{ha}^{-1}\right)$ were only significant in 2017 . In that case, the conventional treatments achieved higher values $\left(30 \mathrm{~kg} \mathrm{~N} \mathrm{ha}^{-1}\right)$ than the treatments with organics as initial fertilisers (13-19 $\left.\mathrm{kg} \mathrm{N} \mathrm{ha}^{-1}\right)$.

\section{Discussion}

\subsection{Periods Affecting Grain Protein Content (GPC) Prediction in Wheat}

The $\mathrm{N}$ accumulated at pre-anthesis, mid-anthesis (GS65), and post-anthesis may affect $\mathrm{N}$ partitioning at the plant level [17] and, thus, the GPC values in wheat crop. In the present study, each $\mathrm{kg}$ of N applied at GS30 (pre-anthesis period) had a different effect depending on the growing season. Although grain total N was similar in 2015 and 2017 (Table 2), the GPC values were higher in 2017 than in 2015 (Table 1). In 2017, rain did not alter the $\mathrm{N}$ application at GS30, and this dry period persisted until GS37 (Table S3), causing a late $\mathrm{N}$ uptake (from GS37 onwards), low yields (3,800-7000), and higher GPC values (8.4-13.3\%). In the 2017 growing season, the NDVI values started increasing from GS37, and biomass accumulation (sink size) was low from GS30 to GS37 (data not shown). López-Bellido et al. [1] reported that high values of the grain $\mathrm{N}$ concentration and low yields were obtained in the years with dry conditions, such as 2017 (Table S3). Additionally, some authors have reported significant increases in the GPC in wheat in the same edaphoclimatic area when $\mathrm{N}$ is applied after GS37 [2,9]. In relation to the 2016 growing season, the grain total $\mathrm{N}$ was higher than that in the other two growing seasons (Table 2). In 2016, the $\mathrm{N}$ applied at GS30 had a huge effect on the yield because, as the N rate applied at GS30 increased, the yield values increased more than that in the other two growing seasons. By contrast, the GPC values did not increase with the increases in the $\mathrm{N}$ rate applied at GS30 (Table 1). The grain total N values, high yields, and achieved GPC values showed a clear dilution effect. In 2016, the NDVI values were high from GS30 to GS65 (data not shown). Thus, the crop sink capacity was high since early in the growing season. Bogard et al. [18] showed that an increased crop sink capacity strongly affects the grain yield. The issue is that the grain yield and grain quality are difficult to improve simultaneously due to the negative relationship between them [5]. Increasing the yield might have an important effect on reducing the GPC due to the dilution effect of carbon-based compounds $[1,19,20]$. Fuertes-Mendizábal et al. [2] mentioned that climatic conditions in Araba could lead to very high yields, and therefore, to a low GPC due to the dilution effect. A drawback of the remarkable increase in grain yield obtained through breeding in wheat has been the decreased GPC [21,22].

Yara N-Tester ${ }^{\mathrm{TM}}$ readings taken at mid-anthesis (GS65) in the leaf flag could explain the GPC variability in the 2015 (Figure 1a) and 2017 (Figure 1c) growing seasons $\left(R^{2}=68 \%\right.$ and $77 \%$, respectively). That correlation was reasonable because the flag-leaf provides $\mathrm{N}$ more directly to the spike, and a strong depletion of more than $50 \%$ occurs in the flag-leaf $\mathrm{N}$ content during the grain-filling period [23]. However, the relationship between the chlorophyll meter readings and GPC variability was growing season dependent. Thus, in 2016, it was not possible to explain the GPC variability from the Yara N-Tester ${ }^{\mathrm{TM}}$ readings (Figure 1b). The Cate-Nelson test showed that the critical values in 2015 divided the population into two different subpopulations (one with higher GPC values, and the other with lower GPC values), whereas the Yara N-Tester ${ }^{\mathrm{TM}}$ and GPC values differed in their relationship. That division matched with yields of approximately $8000 \mathrm{~kg} \cdot \mathrm{ha}^{-1}$. When the yields exceeded $8000 \mathrm{~kg} \cdot \mathrm{ha}^{-1}$ (Figure $2 \mathrm{~b}$ ), no clear pattern in the relationship was observed between Yara N-Tester ${ }^{\mathrm{TM}}$ values and GPC values, similar to the findings for most of the treatments in 2016 (except for the treatments with $0 \mathrm{~kg} \mathrm{~N} \cdot \mathrm{ha}^{-1}$ applied at GS30) and treatments with the highest $\mathrm{N}$ rates in 2015. De Oliveira Silva et al. [24] mentioned different hypotheses to explain the opposite relationship between grain yield and protein, such as 
dilution of protein in higher yield, competition for energy and assimilates between biomass and $\mathrm{N}$ during grain formation or the different accumulation rates between grain protein and carbohydrates during grain filling period. However, when the yields were lower than $8000 \mathrm{~kg} \cdot \mathrm{ha}^{-1}$, the GPC variability prediction capacity from Yara N-Tester ${ }^{\mathrm{TM}}$ readings was similar in the three growing seasons $\left(R^{2}=0.75\right.$; Figure 2a). Other authors, such as Turley et al. [25] with yields ranging from 3800 to $8500 \mathrm{~kg} \cdot \mathrm{ha}^{-1}$ and López-Bellido et al. [1] with yields ranging from 4000 to $11,000 \mathrm{~kg} \mathrm{ha}^{-1}$, showed that taking chlorophyll meter readings at the leaf flag from GS60 to GS69 was adequate for GPC variability prediction. They remarked that, when the yields were high, chlorophyll meter readings presented higher variability than when the yields were lower. Le Bail et al. [26] suggested that, together with the chlorophyll meter readings, the ear number per square metre should be measured to obtain a measurement related to the yield. Models to predict wheat yields have been developed $[27,28]$ that allow the determination of the yields in advance and predict how the yield would affect the GPC values.

In 2016, the post-anthesis N increase in the aerial part was higher than that in the other two growing seasons (Table 2), likely because of the higher amount of biomass accumulated throughout the growing season, justifying the high yield values. Additionally, Mi et al. [29] reported that a high sink size promotes the post-anthesis $\mathrm{N}$ uptake to meet the crop $\mathrm{N}$ requirements. The $\mathrm{N}$ uptake in the post-anthesis period can contribute from 5 to $50 \%$ of the grain N, but it depends on the environmental conditions [7]. Giunta et al. [21] mentioned that rainfall during post-anthesis in particular was the main driver of grain yield and GPC, either directly or via its interaction with nitrogen availability. The mean rainfall of the area in the period between GS65 to harvest (1981-2010) was $81 \mathrm{~mm}$ [30]. In this study, wet conditions occurred in the three growing seasons after mid-anthesis (Table S3), with the total rainfall being $56 \mathrm{~mm}$ in 2015, $71 \mathrm{~mm}$ in 2016, and $114 \mathrm{~mm}$ in 2017. The number of days elapsed (Table S3) in 2016 from GS65 to harvest was more (69) than that in 2017 (63) and 2015 (54). In 2016, the soil moisture was higher, and the crop had more time to absorb $\mathrm{N}$ than in the other two growing seasons. The higher uptake capacity and the more time elapsed in the post-anthesis period might explain the higher post-anthesis $\mathrm{N}$ increase. The effect of the post-anthesis N increase on the variability of the GPC values in winter wheat was also described by Monaghan et al. [17]. They concluded that the significance of the post-anthesis $\mathrm{N}$ absorbance in the GPC variability is related to the different $\mathrm{N}$ partitioning accumulated before and after anthesis. The $\mathrm{N}$ absorbed after anthesis is more efficiently destined to the grain because the $\mathrm{N}$ absorbed after anthesis does not include the crop growth response [18]. However, it is very complex to predict how much $\mathrm{N}$ will be absorbed by the crop in the post-anthesis period [14]. The GPC value range was similar in 2015 and 2016, although the chlorophyll meter readings were lower in 2016 than in 2015. Another reason that could make the GPC variability prediction difficult is predicting how efficiently the plant will translocate $\mathrm{N}$ into the grain in the grain-filling period (GS60-GS90) [14]. In the present experiment, the amount of $\mathrm{N}$ translocated to grains from the crop total $\mathrm{N}$ was $80 \%$ or higher (data not shown). Fuertes-Mendizábal et al. [23], using the same wheat variety and under the same edaphoclimatic conditions, found that the NHI (Nitrogen Harvest Index) values ranged between $75 \%$ and $82 \%$.

In summary, the chlorophyll meter readings can predict the GPC values when the yields are lower than $8000 \mathrm{~kg} \mathrm{~N} \mathrm{ha}^{-1}$, but not when the yields are higher. The established sink size and post-anthesis conditions may affect that prediction, as in 2016. Some authors have mentioned that the GPC predictability from chlorophyll meters is better when the readings are taken at the beginning of the milk stage (GS71, [6]) than at the anthesis stage [26]. However, López-Bellido et al. [1] suggested that taking chlorophyll meter readings later in the growing season would improve the predictability, but leaf senescence (starting at medium milk; GS75, [6]) should be considered. Additionally, it would be too late to perform $\mathrm{N}$ application. 


\subsection{Minimum Chlorophyll Meter Readings to Achieve GPC Values of $12.5 \%$}

The recommended level of GPC needed for the necessary bread-making quality should be higher than $12.5 \%$ [8]. However, it is difficult to ensure that this value will be achieved because many factors influence the grain-filling process (GS60-GS90) [17]. As stated above, achieving the GPC needed for the necessary bread-making quality is complex under the humid Mediterranean conditions of Araba using the usual fertiliser practices (last N application at GS30). Additionally, the commonly used varieties, such as Cezanne variety, have been selected to obtain high yields rather than to obtain a high GPC. The $12.5 \%$ value was only achieved in 2017 with the highest N rate at GS30 $\left(160 \mathrm{~kg} \mathrm{~N} \cdot \mathrm{ha}^{-1}\right)$ in the three initial fertilisation treatments and with yields ranging from 6000 to $7000 \mathrm{~kg} \mathrm{ha}^{-1}$. To enhance the GPC, it would be useful to determine the minimum Yara $\mathrm{N}$-Tester ${ }^{\mathrm{TM}}$ reading value to achieve the required bread-making quality. As mentioned above, predicting the GPC variability using Yara N-Tester ${ }^{\mathrm{TM}}$ in this area under the humid Mediterranean climate was only possible when the yields were lower than $8000 \mathrm{~kg} \cdot \mathrm{ha}^{-1}$. Several authors have established minimum chlorophyll meter readings to achieve the GPC value of $12.5 \%$ [1,16,25]. Some of those studies used Minolta SPAD, which is a chlorophyll meter similar to Yara NTester $^{\mathrm{TM}}$. Both tools measure the light transmitted at 650 and $940 \mathrm{~nm}$ and supply different units in readings, but they are highly correlated as observed in our previous calibration experiments (NTester reading $=14.1 \times$ SPADreading $-61.54 ; R^{2}=0.90$; data not shown). Arregui et al. [11], under the same climatic conditions, also found that both tools are also highly correlated with a very similar equation. Turley et al. [25] reported that, to achieve GPC values approximately $11 \%$ (with yields approximately $8000 \mathrm{~kg} \mathrm{ha}^{-1}$ ), the Minolta SPAD reading values should be 48 , which corresponds to a Yara N-Tester ${ }^{\mathrm{TM}}$ value of 615 (calculated from the previously mentioned equation). In the present study, to achieve GPC values approximately $11 \%$, the Yara N-Tester ${ }^{\mathrm{TM}}$ reading values were similar (approximately 620; Figure 2a) to those proposed by Turley et al. [25]. López-Bellido et al. [1] showed that, to achieve GC values of $12.5 \%$ (with yields approximately $10,000 \mathrm{~kg} \mathrm{ha}^{-1}$ ), the necessary Minolta SPAD reading values at GS65 should be 51 or higher, corresponding to a Yara N-Tester ${ }^{\mathrm{TM}}$ value of 658 (calculated from the previously mentioned equation). In the present study, the Yara N-Tester ${ }^{\mathrm{TM}}$ values to achieve a GPC of $12.5 \%$ were higher (approximately 700, Figure 2a) than those proposed by López-Bellido et al. [1]. Miller et al. [16] reported that, tor achieving GPC values of $13 \%$ (with yields ranging from 1100 to $8000 \mathrm{~kg} \cdot \mathrm{ha}^{-1}$ ), the necessary Minolta SPAD readings should be higher than 40 , which corresponds to Yara N-Tester ${ }^{\mathrm{TM}}=503$ (calculated from the previously mentioned equation), with the values lower than those required in the present study (approximately 720; Figure 2a). The variation in the results demonstrates that it is necessary to be cautious regarding the universality of chlorophyll meter values across geographical locations, as López-Bellido et al. [1] reported. Additionally, the wheat variety should also be considered because each variety should have its own calibration [4]. To generalize the relationship between the chlorophyll meter readings and GPC values, some authors have proposed the use of normalised values [4], which are calculated as a percentage by assessing $100 \%$ to a non-limiting area of the field. However, data normalisation has limitations because finding a control strip that is representative of the entire field is challenging. Ravier et al. [31] showed that it is not easy to ensure that an overfertilised fringe is not $\mathrm{N}$ deficient, thereby complicating the use of normalised data. Additionally, using normalised values makes the use of chlorophyll meters more complicated for farmers. In the present study, the GPC predictability was the worst using Yara N-Tester ${ }^{\mathrm{TM}}$ normalised values (data not shown). Hoel [32] reported that correction factors (as +10 or -10 , or +20 or -20 ) could be used to normalise the differences among varieties when absolute chlorophyll meter readings are used. Hoel [32] reported that, with some varieties, it was not necessary to use a correction value because they presented similar leaf greenness. 


\section{Materials and Methods}

\subsection{Study Site}

Three field trials were established in Arkaute (Araba, Basque Country, Spain) at NEIKER facilities in three consecutive wheat growing seasons defined as 2015, 2016, and 2017 in different fields under rainfed conditions. The three field trials were flat, presented similar characteristics, and the distance among them was $130 \mathrm{~m}$. Other soil properties were described previously [33].

\subsection{Climate}

The climate of the area was humid Mediterranean according to the water regime of Papadakis' [34] classification. The total rainfall $(\mathrm{mm})$ and days elapsed between relevant key wheat growing stages in the three growing seasons are shown in Table S3.

\subsection{Experimental Setup and Treatments}

The experiment was a factorial randomized complete block design with three factors (year, initial fertilisation, and $\mathrm{N}$ rate at stem elongation) and four replicates. Three kinds of initial fertilization were applied: Dairy slurry $\left(40 \mathrm{t} \cdot \mathrm{ha}^{-1}\right)$, sheep farmyard manure $\left(40 \mathrm{t} \cdot \mathrm{ha}^{-1}\right.$ ), and conventional treatment (no organic fertilizer basal dressing and $40 \mathrm{~kg}$ $\mathrm{N} \cdot \mathrm{ha}^{-1}$ at tillering). These three types of fertilization were combined with five $\mathrm{N}$ rates (calcium ammonium nitrate, NAC 27\%) in the topdressings applied at GS30 (0, 40, 80, 120, and $160 \mathrm{~kg} \mathrm{~N} \cdot \mathrm{ha}^{-1}$ ). Apart from the treatments, two controls were established (Table 3): A control without $\mathrm{N}$ fertilisation $(0 \mathrm{~N})$, and an overfertilised control plot $(280 \mathrm{~N})$. Information regarding the organic manure characteristics and application was previously described [33]. Soft wheat (Triticum aestivum var. Cezanne) was sown at a $220 \mathrm{~kg}$ seed $\cdot \mathrm{ha}^{-1}$ rate on 24-11-2014, 06-11-2015, and 18-11-2016, and was harvested on 21-07-2015, 2-08-2016, and 2-08-2017.

Table 3. $\mathrm{N}$ application rates and timing in three initial fertilisation treatments and three growing seasons $(2015,2016$, and 2017) in the field experiment located in Arkaute. Control $(0 \mathrm{~N})$ and overfertilised (280 N). GS21, beginning of tillering; GS30, stem elongation [6].

\begin{tabular}{|c|c|c|c|}
\hline Initial Fertilisation & $\begin{array}{l}\text { Topdressing at GS21 } \\
\left(\mathrm{kg} \mathrm{N} \cdot \mathrm{ha}^{-1}\right)\end{array}$ & $\begin{array}{c}\text { Topdressing at GS30 } \\
\left(\mathrm{kg} \mathrm{N} \cdot \mathrm{ha}^{-1}\right)\end{array}$ & $\begin{array}{c}\text { Treatment } \\
\text { Identification }\end{array}$ \\
\hline $\begin{array}{c}\text { Conventional } \\
{[-]}\end{array}$ & 40 & $\begin{array}{c}0 \\
40 \\
80 \\
120 \\
160\end{array}$ & $\begin{array}{c}40 \mathrm{~N}+0 \mathrm{~N} \\
40 \mathrm{~N}+40 \mathrm{~N} \\
40 \mathrm{~N}+80 \mathrm{~N} \\
40 \mathrm{~N}+120 \mathrm{~N} \\
40 \mathrm{~N}+160 \mathrm{~N}\end{array}$ \\
\hline $\begin{array}{l}\text { Dairy Slurry (DS) } \\
\quad\left[40 \mathrm{t}^{\left.-\mathrm{ha}^{-1}\right]}\right.\end{array}$ & - & $\begin{array}{c}0 \\
40 \\
80 \\
120 \\
160\end{array}$ & $\begin{array}{c}\text { DS }+0 \mathrm{~N} \\
\text { DS }+40 \mathrm{~N} \\
\text { DS }+80 \mathrm{~N} \\
\text { DS }+120 \mathrm{~N} \\
\mathrm{DS}+160 \mathrm{~N}\end{array}$ \\
\hline $\begin{array}{c}\text { Sheep manure (SM) } \\
{\left[40 \mathrm{t} \cdot \mathrm{ha}^{-1}\right]}\end{array}$ & - & $\begin{array}{c}0 \\
40 \\
80 \\
120 \\
160\end{array}$ & $\begin{array}{c}\mathrm{SM}+0 \mathrm{~N} \\
\mathrm{SM}+40 \mathrm{~N} \\
\mathrm{SM}+80 \mathrm{~N} \\
\mathrm{SM}+120 \mathrm{~N} \\
\mathrm{SM}+160 \mathrm{~N}\end{array}$ \\
\hline Control [-] & - & - & $0 \mathrm{~N}$ \\
\hline Overfertilised [-] & 80 & 200 & $280 \mathrm{~N}$ \\
\hline
\end{tabular}

\subsection{Yield and GPC}

Grain yields were harvested at crop maturity using a plot harvester $(1.5 \mathrm{~m} \times 8 \mathrm{~m})$ and were converted to a $12 \%$ dry matter basis. The grain samples were oven-dried at $70{ }^{\circ} \mathrm{C}$ for at least 48 hours and then ground through a 1-mm screen before the determination of 
the total $\mathrm{N}$ concentration using the Kjeldhal procedure [35]. GPC was determined as the product of the grain $\mathrm{N}$ concentration multiplied by 5.7 [36].

4.5. Increase in the N Content in the Aerial Part during the Post-anthesis Period (from GS65 to Harvest)

$\mathrm{N}$ accumulation in the aerial part of the wheat crop during the post-anthesis period (from GS65 to harvest) was measured in all conventional treatments, DS + 0N, SM + 0N, and $0 \mathrm{~N}$ (Table 3), and was calculated as follows:

(1) Post-anthesis N increase $\left(\mathrm{kg} \mathrm{N} \cdot \mathrm{ha}^{-1}\right)=$ Crop Total N - GS65 Total N (1)

(2) Crop Total $\mathrm{N}$ content was calculated as: Crop Total $\mathrm{N}\left(\mathrm{kg} \mathrm{N} \cdot \mathrm{ha}^{-1}\right)=$ Grain Total $\mathrm{N}\left(\mathrm{kg} \mathrm{N} \cdot \mathrm{ha}^{-1}\right)+$ Straw Total N $\left(\mathrm{kg} \mathrm{N} \cdot \mathrm{ha}^{-1}\right)$ (2) where Grain Total N content was calculated as:

(3) Grain Total N (kg N.ha $\left.{ }^{-1}\right)=$ Grain Yield $\left(\mathrm{kg} \cdot \mathrm{ha}^{-1}\right) \times$ Grain N concentration (\%) (3) where Straw Total $\mathrm{N}$ content was calculated as:

(4) Straw Total N ( $\left.\mathrm{kg} \mathrm{N} \cdot \mathrm{ha}^{-1}\right)=$ Straw Yield $\left(\mathrm{kg} \cdot \mathrm{ha}^{-1}\right) \times$ Straw N concentration (\%) (4)

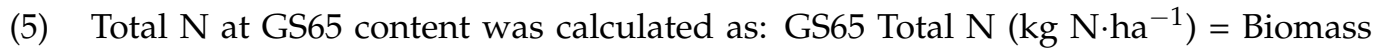
$\left(\mathrm{kg} \cdot \mathrm{ha}^{-1}\right) \times \mathrm{N}(\%)(5)$

Biomass was calculated, and the $\mathrm{N}$ concentration was analysed using the Kjeldhal procedure under all conditions [35].

\subsection{Measurements Using Yara N-Tester ${ }^{T M}$}

Yara N-Tester ${ }^{\mathrm{TM}}$ (Yara International ASA, Oslo, Norway) is a chlorophyll meter that measures light transmitted by the plant leaf at two different wavelengths, 650 (red light) and $940 \mathrm{~nm}$ (near-infrared light). The instrument processes a digital reading calculated from the light transmitted by the plant leaf and light transmitted with no sample.

The chlorophyll meter calculates a value $(M)$ that is determined as follows:

$$
M=k \cdot \log 10 \frac{\operatorname{Io}(650) I(960)}{I(650) \operatorname{Io}(960)}
$$

where $I o$ is the intensity of the incident monochromatic light and $I$ is the intensity of the transmitted light. The $\mathrm{K}$ value is instrument dependent.

Yara N-Tester ${ }^{\mathrm{TM}}$ readings were taken for all treatments (Table 3) and GS65. The measurements were taken in the last fully developed leaf in the middle of the blade. Thirty main-stem flag leaves were measured at random along with the plots. A mean value was calculated for each plot. The acquired values were expressed as the relative chlorophyll content and were unitless.

\subsection{Statistical Analysis}

The three factors that influence the GPC, yield, Yara N-Tester ${ }^{\mathrm{TM}}$ at GS65, the N content in the post-anthesis period, and the grain total $\mathrm{N}$ content were the growing season, initial fertilisation treatment, and N rate at GS30, were analysed by analysis of variance (ANOVA) using 'R 3.2.5' software. To separate the means, Duncan's test was used $(p<0.05)$ using the $\mathrm{R}$ package agricolae.

Coefficients of determination $\left(R^{2}\right)$ were calculated for the relationships between the Yara N-Tester ${ }^{\mathrm{TM}}$ values at GS65 and GPC (\%) for each growing season $(2015,2016$, and 2017) using 'R 3.2.5' software. Otherwise, the Cate-Nelson procedure was performed to determine the accuracy of Yara N-Tester ${ }^{\mathrm{TM}}$ values at GS65 to predict GPC (\%). The Cate-Nelson procedure is used to divide data in two populations: One where a change in the $X$ variables is likely to correspond to a change in the $Y$ variable, and the other group where a change in the $X$ is unlikely to correspond to a change in $Y$. 


\section{Conclusions}

The type of initial fertiliser did not affect the GPC values and chlorophyll meter readings at mid-anthesis. Generally, the higher the mineral $\mathrm{N}$ applied at stem elongation, the higher the chlorophyll meter readings and GPC values, because the GPC values are yield dependent. The chlorophyll meter readings at mid-anthesis in wheat might be helpful in estimating the GPC values under humid Mediterranean conditions only when the yields are below $8000 \mathrm{~kg} \cdot \mathrm{ha}^{-1}$. Yara N-Tester ${ }^{\mathrm{TM}}$ readings at mid-anthesis should be higher than 700 in the wheat Cezanne variety to achieve the recommended level of GPC for highquality bread-making flour $(12.5 \%)$ at these yield levels. These results will allow farmers and cooperatives to make better decisions regarding late-nitrogen fertilisation and product sales, but it is necessary to adjust the values to the different varieties or cultivars. Future directions for wheat grain protein estimation should explore new fertilisation strategies including late $\mathrm{N}$ applications with granular mineral fertilisers or foliar applications but always avoiding the $\mathrm{N}$ rate increase.

Supplementary Materials: The following are available online at https:/ /www.mdpi.com/2223-7 $747 / 10 / 2 / 374 /$ s1. Table S1: Duncan's test $(p<0.05)$ results of the differences in the GPC values $(\%)$, yield $\left(\mathrm{kg} \mathrm{ha}^{-1}\right)$, and Yara N-Tester values at mid-flowering (GS65, [6]) among different wheat growing seasons $(2015,2016$ and 2017) for each initial ferti-lisation treatment (conventional, dairy slurry and sheep manure) and each $\mathrm{N}$ dose $\left(0,40,80,120\right.$ and $\left.160 \mathrm{~kg} \mathrm{~N} \mathrm{ha}^{-1}\right)$ applied at stem elongation (GS30, [6]) in the field study at Arkaute. Table S2: Duncan's test $(p<0.05)$ results of the differences in the grain total nitrogen $\left(\mathrm{kg} \mathrm{N} \mathrm{ha}^{-1}\right)$ and post-anthesis ni-trogen increase $\left(\mathrm{kg} \mathrm{N} \mathrm{ha}^{-1}\right)$ among different wheat growing seasons $(2015,2016$ and 2017) for each treatment in the field study at Arkaute. Table S3: Total rainfall $(\mathrm{mm})$, cumulative growing degree days GDD $\left({ }^{\circ} \mathrm{C}\right)$ and days elapsed between wheat growing stages [6] in three growing seasons $(2015,2016$ and 2017) in the field study at Arkaute.

Author Contributions: M.A., A.C., and A.A contributed to the design of this experiment. Field work was accomplished by M.A. and A.C. Data was analysed by M.A. M.A, A.C., and A.A contributed to the interpretation of data. M.A. and A.A. wrote the paper. M.A., A.C., and A.A. All authors have read and agreed to the published version of the manuscript.

Funding: The National Institute of Agricultural and Food Research and Technology (RTA2013-0005701 and RTA2017-00088-C03-00) and the Department for Economic Development and Infrastructures of the Basque Government funded this study. M. Aranguren is the recipient of a predoctoral fellowship from the Department for Economic Development and Infrastructures of the Basque Government.

Informed Consent Statement: Not applicable.

Data Availability Statement: The data presented in this study are available on request from the corresponding author.

Conflicts of Interest: The authors declare that they have no conflicts of interest. The authors declare that they have no competing financial and/or non-financial interests in relation to the work described.

\section{References}

1. López-Bellido, R.J.; Shepherd, C.E.; Barraclough, P.B. Pedicting post-anthesis N requeriments of bread wheat with Minolta SPAD meter. Eur. J. Agron. 2004, 20, 313-320.

2. Fuertes-Mendizábal, T.; Aizpurua, A.; González-Moro, M.; Estavillo, J. Improving wheat breadmaking quality by splitting the N fertilizer rate. Eur. J. Agron. 2010, 33, 52-61. [CrossRef]

3. Gaju, O.; Allard, V.; Martre, P.; Le Gouis, J.; Moreau, D.; Bogard, M.; Hubbart, S.; Foulkes, M.J. Nitrogen partitioning and remobilization in relation to leaf senescence, grain yield and grain nitrogen concentration in wheat cultivars. Field Crop. Res. 2014, 155, 213-223. [CrossRef]

4. Diacono, M.; Rubino, P.; Montemurro, F. Precision nitrogen management of wheat. A review. Agron. Sustain. Dev. 2013, 33, 219-241. [CrossRef]

5. Simmonds, N.W. The relation between yield and protein in cereal grain. J. Sci. Food Agric. 1995, 67, 309-315. [CrossRef]

6. Zadoks, J.C.; Chang, T.T.; Konzak, C.F. A decimal code for the growth stages of cereals. Weed Res. 1974, 14, 415-421. [CrossRef]

7. Fuertes-Mendizábal, T.; Gonzalez-Murua, C.; González-Moro, M.B.; Estavillo, J.-M. Late nitrogen fertilization affects nitrogen remobilization in wheat. J. Plant Nutr. Soil Sci. 2011, 175, 115-124. [CrossRef] 
8. RD 677/2016: Real Decreto 677/2016, de 16 de Diciembre, por el Que se Aprueba la Norma de Calidad para las Harinas, las Sémolas y Otros Productos de la Molienda de los Cereales; Boletín Oficial del Estado, Sec I, 88519; Ministerio de la Presidencia y para las Administraciones Territoriales: Madrid, Spain, 2016.

9. Ortuzar-Iragorri, M.A.; Aizpurua, A.; Castellón, A.; Alonso, A.; José, M.; Estavillo, J.M.; Besga, G. Use of an N-tester chlorophyll meter to tune a late third nitrogen application to wheat under humid Mediterranean conditions. J. Plant Nutr. 2017, 41, 627-635.

10. Wang, Z.; Wang, J.; Liu, L.; Huang, W.; Zhao, C.; Wang, C. Prediction of grain protein content in winter wheat (Triticum aestivum L.) using plant pigment ratio (PPR). Field Crop. Res. 2004, 90, 311-321. [CrossRef]

11. Arregui, L.; Lasa, B.; Lafarga, A.; Irañeta, I.; Baroja, E.; Quemada, M. Evaluation of chlorophyll meters as tools for N fertilization in winter wheat under humid Mediterranean conditions. Eur. J. Agron. 2006, 24, 140-148. [CrossRef]

12. Ortuzar-Iragorri, M.A.; Alonso, A.; Castellón, A.; Besga, G.; Estavillo, J.M.; Aizpurua, A. N-tester use in soft winter wheat: Evaluation of nitrogen status and grain yield prediction. Agron. J. 2005, 97, 1380-1389. [CrossRef]

13. Hansen, P.M.; Jørgensen, J.R.; Thomsen, A. Predicting grain yield and protein content in winter wheat and spring barley using repeated canopy reflectance measurements and partial least squares regression. J. Agric. Sci. 2002, 139, 307-318. [CrossRef]

14. Magney, T.S.; Vierling, L.A.; Eitel, J.U.; Huggins, D.R.; Garrity, S.R. Response of high frequency Photochemical Reflectance Index (PRI) measurements to environmental conditions in wheat. Remote Sens. Environ. 2016, 173, 84-97. [CrossRef]

15. Aranguren, M.; Castellón, A.; Aizpurua, A. Crop sensor based non-destructive estimation of nitrogen nutritional status, yield, and grain protein content in wheat. Agriculture 2020, 10, 148. [CrossRef]

16. Miller, R.O.; Pettygrove, S.; Denison, R.F.; Jackson, L.F.; Cahn, M.; Plant, R.; Kearney, T. Site-Specific Relationships between Flag Leaf Nitrogen, SPAD Meter Values and Grain Protein in Irrigated Wheat. In Proceedings of the Fourth International Conference on Precision Agriculture, St. Paul, MN, USA, 19-22 July 1998; Wiley: Hoboken, NJ, USA, 1999; pp. 113-122.

17. Monaghan, J.M.; Snape, J.W.; Chojecki, A.J.S.; Kettlewell, P.S. The use of grain protein deviation for identifying wheat cultivars with high grain protein concentration and yield. Euphytica 2001, 122, 309-317. [CrossRef]

18. Bogard, M.; Allard, V.; Brancourt-Hulmel, M.; Heumez, E.; Machet, J.M.; Jeuffroy, M.H.; Gate, P.; Martre, P.; LeGouis, J. De-viations from the grain protein concentration-grain yield negative relationship are highly correlated to post-anthesis $\mathrm{N}$ uptake in winter wheat. J. Exp. Bot. 2010, 61, 4303-4312. [CrossRef]

19. Acreche, M.M.; Slafer, G.A. Variation of grain nitrogen content in relation with grain yield in old and modern Spanish wheats grown under a wide range of agronomic conditions in a Mediterranean region. J. Agric. Sci. 2009, 147, 657-667. [CrossRef]

20. Zhou, X.; Kono, Y.; Win, A.; Matsui, T.; Tanaka, T.S.T. Predicting within-field variability in grain yield and protein content of winter wheat using UAV-based multispectral imagery and machine learning approaches. Plant Prod. Sci. 2020, 1-15. [CrossRef]

21. Giunta, F.; Pruneddu, G.; Motzo, R. Grain yield and grain protein of old and modern durum wheat cultivars grown under different cropping systems. Field Crop. Res. 2019, 230, 107-120. [CrossRef]

22. Iannunci, A.; Fares, C.; Codianni, P. Influence of nitrogen levels on bio-agronomic and quality traits of tretaploid wheats under organic farming. Ann. Appl. Biol. 2018, 173, 1-15. [CrossRef]

23. Fuertes-Mendizábal, T.; Estavillo, J.M.; Duñabeitia, M.K.; Huérfano, X.; Castellón, A.; González-Murua, C.; Aizpurua, A.; González-Moro, M.B. 15N natural abundance evidences a better use of N sources by late nitrogen application in bread wheat. Front. Plant Sci. 2018, 9, 853. [CrossRef]

24. Silva, A.D.O.; Ciampitti, I.A.; Slafer, G.A.; Lollato, R.P. Nitrogen utilization efficiency in wheat: A global perspective. Eur. J. Agron. 2020, 114, 126008. [CrossRef]

25. Turley, D.B.; Sylvester-Bradley, R.; Dampney, P.M.R. Foliar-Applied Nitrogen for Grain Protein and Canopy Management of Wheat; HGCA Research Review, No. 47; Home Grown Cereals Authority: London, UK, 2001.

26. Le Bail, M.; Jeuffroy, M.-H.; Bouchard, C.; Barbottin, A. Is it possible to forecast the grain quality and yield of different varieties of winter wheat from Minolta SPAD meter measurements? Eur. J. Agron. 2005, 23, 379-391. [CrossRef]

27. Zhang, D.; Shen, J.; Zhang, F.; Li, Y.; Zhang, W. Carbon footprint of grain production in China. Sci. Rep. 2017, 7, 1-11. [CrossRef]

28. Aranguren, M.; Castellón, A.; Aizpurua, A. Wheat Yield Estimation with NDVI Values Using a Proximal Sensing Tool. Remote Sens. 2020, 12, 2749. [CrossRef]

29. Mi, G.; Tang, L.; Zhang, F.; Zhang, J. Is nitrogen uptake after anthesis in wheat regulated by sink size? Field Crop. Res. 2000, 68, 183-190. [CrossRef]

30. Euskalmet, Euskal Meteorologia Agentzia. 2019. Available online: http://www.euskalmet.euskadi.eus/ (accessed on 10 April 2020).

31. Ravier, C.; Meynard, J.-M.; Cohan, J.-P.; Gate, P.; Jeuffroy, M.-H. Early nitrogen deficiencies favor high yield, grain protein content and $\mathrm{N}$ use efficiency in wheat. Eur. J. Agron. 2017, 89, 16-24. [CrossRef]

32. Hoel, B.O. Chlorophyll Meter Readings in Winter Wheat: Cultivar Differences and Prediction of Grain Protein Content. Acta Agric. Scand. Sect. B Plant Soil Sci. 2002, 52, 147-157. [CrossRef]

33. Aranguren, M.; Castellón, A.; Aizpurua, A. Crop sensor-based in-season nitrogen management of wheat with manure ap-plication. Remote Sens. 2019, 11, 1094. [CrossRef]

34. Papadakis, J. Climates of the World and Their Agricultural Potentialities; Papadakis, J.: Buenos Aires, Argentina, 1966. 
35. AOAC-Association of Official Analytical Chemists International. Plants. In Official Methods of AOAC International, 16th ed.; Patricia, C., Ed.; AOAC International: Gaithersburg, MD, USA, 1999; Volume 24, p. 127.

36. Teller, G.L. Non-protein nitrogen compounds in cereals and their relation to the nitrogen factor for protein in cereals and bread. Cereal Chem. 1932, 9, 261-274. 